\title{
Effects of endocannabinoids in pentylenetetrazole induced seizures in mice
}

\author{
Farelerde pentilentetrazol ile oluşturulan epilepsiye endokannabinoidlerin etkisi
}

\author{
Engin Yücel ${ }^{1 *}$, Zühal Aktuna ${ }^{2}$, İsmail Semih Keskil ${ }^{3}$ \\ 1.Alanya Alaaddin Keykubat University, Education and Research Hospital, Neurosurgery Clinic, Alanya, Turkey \\ 2.Yuksek Ihtisas University, Faculty of Medicine, Pharmacology Clinic, Ankara,Turkey \\ 3. Yuksek Ihtisas University, Department of Electroneurophysiology, Ankara, Turkey
}

\section{ABSTRACT}

Aim: Pentylenetetrazole (PTZ) is an agent widely used for the assessment of putative anticonvulsant drugs and is supposed to induce repetitive firing of nerve fibers as well as shorten the refractory period. Anandamide is an endocannabinoid synthesized in neurons, excreted by depolarization and inactivated very quickly. Ethanol is a psychoactive substance which has an anticonvulsive effect after acute application, although repeated administrations of high doses lead to proconvulsant actions. In order to explore whether endocannabinoids are effective in the treatment of epilepsy or not, we aimed to study the effect of anandamide on PTZ induced epileptic seizures in mice by determining which types of cannabinoid receptors are.

Materials and methods: In our small animal experimental model, thirty-two Swiss albino male mice weighing 25-35 g were used. During the study, the experimental animals were randomly divided into four groups as the control, anandamide, synthetic analogue of anandamide (WIN 55.212-2), and ethanol and the number of epileptic attacks, duration of the first epileptic attack, the total duration of the epileptic attacks and the latency time to the first attack after PTZ injection, mortality and the day of kindling development were compared in each group.

Results: The mortality rate and seizure duration were significantly lower in all of the anandamide, WIN 55.212-2 and ethanol groups. After pre-PTZ injection of ethanol and anandamide, latency periods were significantly higher, without any difference between the groups. However, a similar relationship was not present between WIN 55.212-2 and ethanol.

Conclusion: Our data showed that the antiepileptic effect of endocannabinoid anandamide observed was due to the its solvent, ethanol; however this effect was not found with its analogue WIN 55.212-2. Although both endocannabinoids resulted in interaction in the cannabinoid receptors, this difference may be the result of their different pharmacokinetics, metabolisms or degradation products and active metabolites.

Keywords: Endocannabinoids, Pentylenetetrazole, Seizure, Mice, Ethanol, Anandamide

\section{Öz}

Amaç: Pentilentetrazol (PTZ) yaygın antikonvülzan olduğu varsayılan ilaçların değerlendirilmesi için kullanılan bir maddedir ve sinir liflerinin tekrarlayan şekilde uyarımasını ve refrakter süresinin kısaltılmasını sağlar. Anandamid, nöronlarda sentezlenen ve depolarizasyon sırasında atılan bir endokannabinoiddir ve çok hızl bir şekilde inaktive olur. Epilepsi gibi sinirsel bozukluklarda, yüksek anandamid düzeyleri gözlenmiştir. Etanol akut bir uygulama sonrası, antikonvülsif etkisi olan bir psikoaktif maddedir, ancak yüksek dozlarda tekrar tekrar verilmesi prokonvülsan etkiye yol açar. Bu çalışmada amacımız endokannabinoidlerin farelerde PTZ kaynaklı epileptik nöbetleri indükleyen anandamidin etkisini, kannabinoid reseptörlerinin tiplerini belirleyerek araşıırmaktı.

Materyal ve metod: Küçük hayvan deney modelimizde, $25-35$ gr ağırlığında otuz iki İviçre albino erkek fare kullanıldı. Çalışma sırasında, deney hayvanları; kontrol, anandamid, anandamidin sentetik analoğu (WIN 55.212-2) ve etanol olarak rastgele dört gruba ayrıldı. Epileptik atakların sayısı, ilk epileptik atak süresi, epileptik atakların toplam süresi ve PTZ enjeksiyonundan sonraki ilk ataktaki bekleme, mortalite ve alevlenme gelişim süresi her grupla karşılaştırıldı.

Bulgular: WIN 55.212-2, anandamid ve etanol gruplarının tümünde mortalite oranı ve nöbet süresi anlamlı olarak daha düşüktü. PTZ enjeksiyonu öncesi etanol ve anandamid uygulandığında gecikme süreleri anlamlı olarak yüksek bulundu; ancak gruplar arasında bir fark yoktu. Bununla birlikte, benzer bir ilişki WIN 55.212-2 ve etanol arasında da mevcut değildi.

Sonuç: Endokannabinoid anandamid'in gözlenen antiepileptik etkisinin, çözücüsü olan etanol'ün etkisine bağlı olduğu söylenebilir; fakat bu etki de analoğu olan WIN 55.212-2 ile gözlenmemiştir. Her iki endokannabinoid de kannabinoid reseptörlerini etkilese de, bunların etkileri arasındaki söz konusu fark, onların farkı farmakokinetik, metabolizma ya da yıkım ürünlerine veya aktif metabolitlerine de bağlı olabilir.

Anahtar Kelimeler: Endokannabinoidler, Pentilentetrazol, Epilepsi, Fare, Ethanol, Anandamid

Received: 17.02.2020 Accepted:30.05.2020 Published (Online):29.10.2020

*Corresponding Author: Engin Yücel, MD. Alanya Alaaddin Keykubat University, Education and Research Hospital, Neurosurgery Clinic, Alanya,Turkey, 05337490595,drengin2005@yahoo.com

ORCID:0000-0001-8910-5359

To cited: Yücel E, Aktuna Z, Keskil IS. Effects of endocannabinoids in pentylenetetrazole induced seizures in mice. Acta Med. Alanya 2020;4(3):209-215. doi:10.30565/medalanya.690410 


\section{INTRODUCTION}

pilepsy is a neurological disorder characterized by chronic seizures in repeating patterns of sudden episodes of loss of consciousness, convulsions and other abnormal motor activities. It is known that excitatory neurotransmitters, such as glutamate and aspartate, are effective in the emergence of epileptic seizures in the mammalian brain. Some information suggests that seizures may be related to an increase in the extracellular concentrations of excitatory amino acids; however, some experimental studies have shown a decrease in the levels of glutamate and aspartate during epileptic seizures [1]. The imbalance between the excitatory and inhibitory neurotransmitters during PTZ-induced seizures is evident in the early stage of the epileptogenic process [2]. Glutamate is metabolized to glutamine in glial cells and transported to the synaptic terminal for subsequent glutamate resynthesis [1]. This observation may explain the high levels of glutamine after PTZ injection. Glutamate facilitates calcium $(\mathrm{Ca})$ influx into the cell by interacting with the $\mathrm{N}$-methyl-D-aspartate (NMDA) subtype of glutamate receptors and increases the Neuronal Nitric Oxide Synthase (nNOS) activity, consequently elevating the Nitric Oxide (NO) levels. NO has a major impact on learning but it may be toxic at high levels [3]. Depending on the stimulating agent and the NO concentration administered, it may show anticonvulsant or proconvulsant effects [4]. Reductions in NO levels produce anticonvulsant effects [5]. On the other hand, inhibitory neurotransmitters such as gamma-aminobutyric acid (GABA) and glycine affect the neuronal stimulatory mechanisms in a reverse way. GABA increases the entry of chloride $(\mathrm{Cl}-)$ into the cell via GABA-A subtype receptors, causes hyperpolarization of the cell membrane and prevents epileptic seizures [5].

Anandamide, isolated from the pig brain in 1992, is an endogenous cannabinoid ligand that shares many of the biochemical and physiological effects of herbal or synthetic cannabinoids $[6,7]$. Anandamide has been detected in the human, rat, porcine, and bovine brains, in the skin and spleen of rats, as well as in the human spleen and heart [8].
The aim of this study was to investigate the effects of endocannabinoids on epileptic seizures and to demonstrate how endocannabinoids would affect epileptic seizures and provide a new perspective for the physiopathology of epilepsy, as well as approaches used in its treatment.

\section{MATERIALS AND METHODS}

The experimental procedure was approved by the Institutional Animal Care and Use Committee of Kırıkkale University (22.02.2005, 2005/37). Every step of the experiment was planned according to animal welfare guidelines.

For the purpose of this study, Pentylenetetrazole (Sigma), Anandamide (Sigma), WIN 55.2122 (RBI, Tocris), and Ethanol (Sigma-Aldrich) chemicals were obtained. In this study, thirty-two Swiss albino male mice weighing 25-35 g were used. The animals were housed in groups of eight per cage and were maintained at a temperature of $20-30^{\circ} \mathrm{C}$ and a humidity level of $50-55 \%$ in a natural light and dark cycle, with free access to food and water. Only active and apparently healthy animals were selected for the experiments. During the study, experimental animals were randomly divided into four groups identified as the control, the anandamide, the WIN 55.212-2, and the ethanol group.

\section{Study groups}

Control group $(n=11)$ received only intraperitoneal injections (ip) of PTZ at a dose of $60 \mathrm{mg} / \mathrm{kg}$.

Anandamide group $(\mathrm{n}=10)$ received $5 \mathrm{mg} / \mathrm{kg}$ anandamide ip followed by the PTZ injection of 60 $\mathrm{mg} / \mathrm{kg}$ ip 10 minutes later.

WIN 55.212-2 group $(n=5)$ received WIN 55.2122 at a dose of $5 \mathrm{mg} / \mathrm{kg}$ ip followed by the PTZ injection of $60 \mathrm{mg} / \mathrm{kg}$ ip 10 minutes later.

Ethanol group $(n=6)$ received $0.10-0.12 \mathrm{ml}$ of ethanol ip followed by the PTZ injection of $60 \mathrm{mg} /$ $\mathrm{kg}$ ip 10 minutes later.

PTZ was diluted in saline to a concentration of 6 $\mathrm{mg} / \mathrm{ml}$. Anandamide was initially diluted in $10 \mathrm{mg} /$ $\mathrm{ml}$ ethanol, followed by a series of dilutions with saline. WIN 55.212-2 was diluted with $2.5 \mathrm{mg} / 2$ $\mathrm{ml}$ ethanol, followed by a series of dilutions with 
saline.

PTZ was administered ip at a dose of $60 \mathrm{mg} / \mathrm{kg}$ in the control group. The animals included in the experiment were observed for the first 30 minutes, to record the length of time until the occurrence of the first epileptic seizure (latency period), the length of the first epileptic seizure, the number of seizures and the total duration of the seizures. Following the observing period in the first 30 minutes following the injection, the animals were observed for another 30 minutes to monitor mortality. In the experimental groups other than the control group, anandamide, WIN 55.212-2 and ethanol injections were administered 10 minutes before the PTZ injections, after which the same observation procedure as the one applied to the control group was conducted with these other experimental groups.

The seizure stages were defined as follows:

Stage 0: No evidence of convulsive activity, normal exploratory activity.

Stage 1: Ear and facial twitching, head nodding, loss of muscle tone and reduced activity.

Stage 2: Head clonus, chronic forelimb convulsions lasting less than 3 seconds (sec).

Stage 3: Chronic forelimb convulsions lasting more than 3 seconds.

Stage 4: Generalized convulsions with tonic extension episodes; full status epilepticus.

Stage 5: Death.

Statistical analysis

Statistical analysis of the data was expressed as the arithmetic mean of the number of experimental data and \pm the standard error of the mean (SE). In all groups, the number of epileptic attacks, duration of the first epileptic attack, the total duration of the epileptic attacks and the latency time to the first attack after PTZ injection, mortality and the day of kindling development, were all compared. Data was assessed by nonparametric (Kruskal-Wallis) analysis of variance and by post hoc Dunn's test. Mortality was evaluated by the Fisher Exact test. $p<0.05$ was considered as statistically significant difference. During the study, "Instat" $\square$ (Graph
Pad, U.S.A.), Excell-2000 $\square$ (Windows Edition) (Microsoft, U.S.A.) and Microsoft Word-2000 (Windows Edition) (Microsoft, U.S.A.) programs were used.

\section{RESULTS}

The latency period, defined as the time elapsed until the first epileptic seizure, was $297.8 \pm 67.2$ seconds (sec) (mean \pm standard error) in the anandamide (n:10) group and $262 \pm 28.6 \mathrm{sec}$ in the ethanol $(n: 6)$ group. The latency period was significantly different in the control, anandamide, WIN 55.212-2 and ethanol experimental groups (Kruskal Wallis, $p=0.0038$ ). It was $155.8 \pm 43.1$ sec and statistically significantly lower in the control group ( $\mathrm{n}: 11)$ compared to the experimental groups (Anandamide vs. control: $p<0.01$, ethanol vs control: $p<0.05$ ) (Figure 1). The latency period of $155.8 \pm 43.1 \mathrm{sec}$ in the control group was not statistically significantly different from the latency period of $171.4 \pm 25.3 \mathrm{sec}$ in the WIN 55.212-2 (n:5) group ( $p>0.05)$ (Figure 1). The latency periods of anandamide (297.8 $\pm 67.2 \mathrm{sec})$ and ethanol $(262 \pm$ $28.6 \mathrm{sec}$ ) groups were not statistically significantly different $(p>0.05)$.

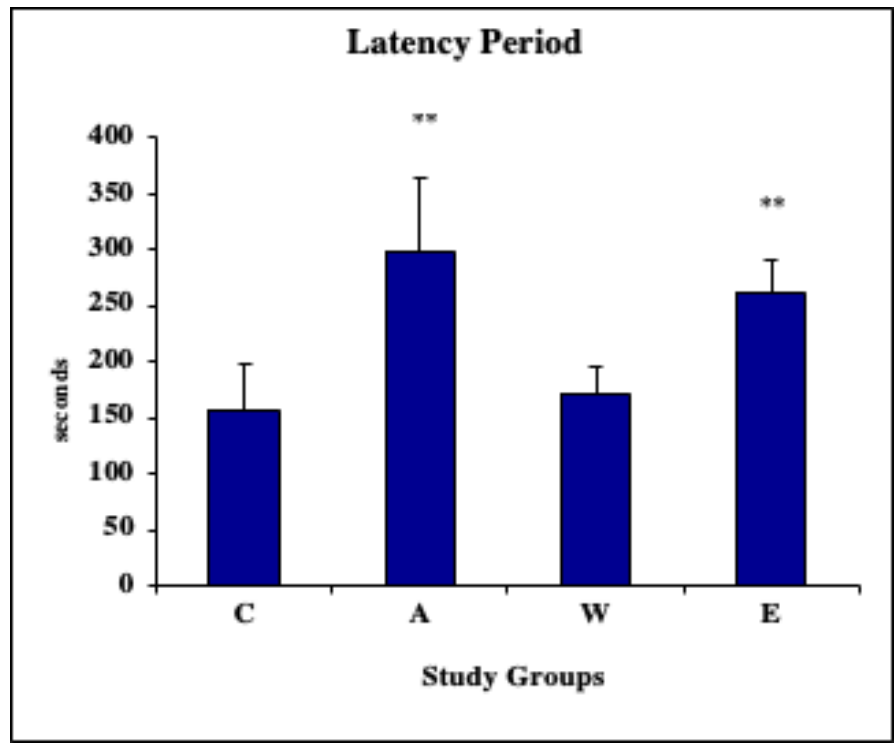

Figure 1: Comparison of the groups for the latency period. $\mathrm{C}=\mathrm{Control} /$ PTZ group, $n=11 ; A=A$ nandamide group, $n=10 ; W=W I N$ group, $n=5$; $\mathrm{E}=$ Ethanol group, $\mathrm{n}=6$

The total duration of epileptic seizures was not statistically significantly different between the control and experimental groups. It was $32.5 \pm$ $12.1 \mathrm{sec}$ in the control group $(\mathrm{n}: 11), 34.71 \pm 17.5$ $\mathrm{sec}$ in the ethanol group $(\mathrm{n}: 6), 23.3 \pm 4.4 \mathrm{sec}$ in the anandamide group ( $\mathrm{n}: 10)$ and $48.4 \pm 17.3 \mathrm{sec}$ 
in the WIN 55.212-2 (n:5) group (Kruskal Wallis, $\mathrm{p}=0.4)$ (Figure 2).

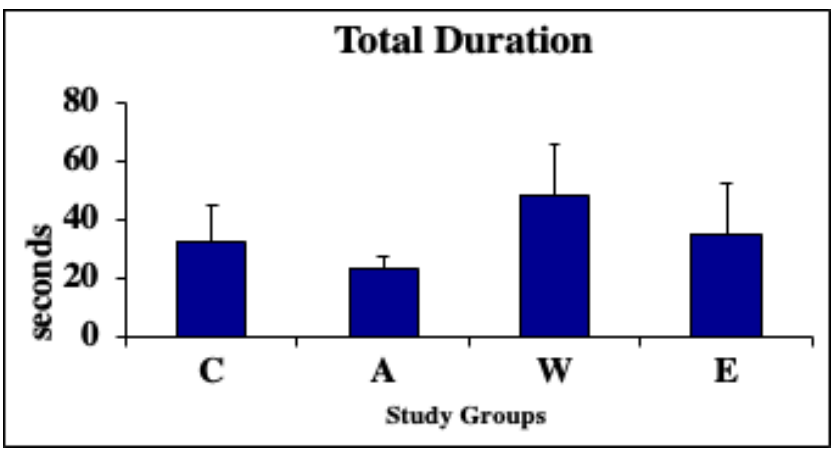

Figure 2: Comparison of the groups for the total duration of seizures. $\mathrm{C}=\mathrm{Control} / \mathrm{PTZ}$ group, $\mathrm{n}=11 ; \mathrm{A}=$ Anandamide group, $\mathrm{n}=10 ; \mathrm{W}=\mathrm{WIN}$ group, $n=5 ; E=E$ thanol group, $n=6$

The length of the first seizure in the experimental animals was statistically significantly different among all groups in the study (Kruskal Wallis, $p=0.0327$ ) (Figure 3). However, the post-hoc binary comparisons between the groups revealed no statistically significant differences between the paired groups. There was no statistically significant difference between the control group $(n: 11)$ and the ethanol group $(n: 6)$ with $16.4 \pm 5.3$ sec and $16.0 \pm 2.1 \mathrm{sec}$, respectively. The length of the first seizure was $18.8 \pm 0.8 \mathrm{sec}$ in the anandamide group $(\mathrm{n}: 10)$ and $20.8 \pm 2.3 \mathrm{sec}$ in the WIN 55.212-2 (n:5) group with no statistically significant differences $(p>0.05)$.

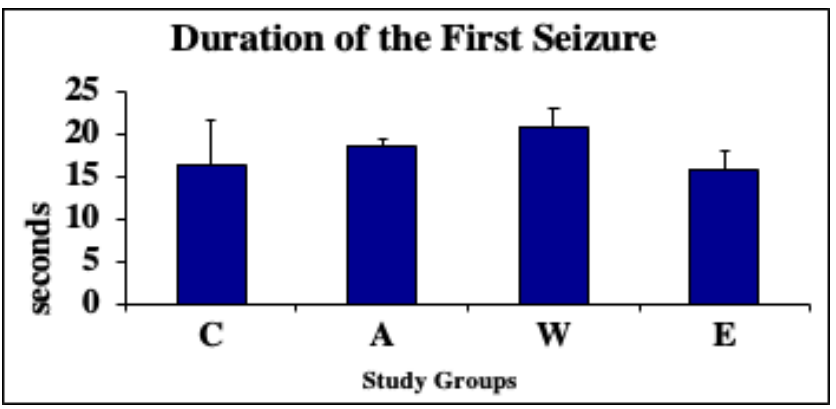

Figure 3: Comparison of the length of the first seizure between the groups. $\mathrm{C}=$ Control/PTZ group, $\mathrm{n}=11 ; \mathrm{A}=$ Anandamide group, $\mathrm{n}=10 ; \mathrm{W}=\mathrm{WIN}$ group, $\mathrm{n}=5 ; \mathrm{E}=$ Ethanol group, $\mathrm{n}=6$

When the total number of seizures was compared between the groups, no statistically significant differences were observed. The total number of seizures was $1.3 \pm 0.2$ in the control $(n: 11)$ group, $1.6 \pm 0.4$ in the ethanol $(n: 6)$ group, $1.2 \pm 0.2$ in the anandamide (n:10) group, and $2.2 \pm 0.6$ in the WIN 55.212-2 group ( $n: 5)(p=0.2715)$ (Figure 4).
Regarding mortality resulting from the epileptic seizures, the mortality rate was $45.50 \%$ in the control group ( $\mathrm{n}: 5 / 11), 0 \%$ in the ethanol (n:0/6) group, $0 \%$ in the anandamide (n:0/10) group, and $20 \%$ in the WIN 55.212-2 (n:1/5) group. The mortality rate was found to be statistically significantly $(p<0.05)$ higher in the control group compared to the other experimental groups. However, there were no statistically significant differences among the mortality rates of $0 \%$ in the ethanol group, $0 \%$ in the anandamide group and $20 \%$ in the WIN 55.212-2 group ( $p>0.05$ ) (Table $1)$.

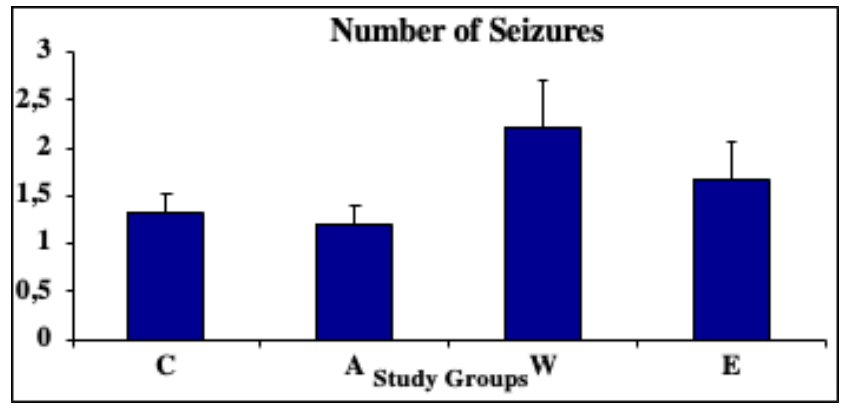

Figure 4: Comparison of the total number of epileptic seizures between the groups. $\mathrm{C}=\mathrm{Control} / \mathrm{PTZ}$ group, $\mathrm{n}=11 ; \mathrm{A}=\mathrm{Anandamide}$ group, $\mathrm{n}=10$; $\mathrm{W}=\mathrm{WIN}$ group, $\mathrm{n}=5$; E=Ethanol group, $\mathrm{n}=6$

Table 1. Mortality Rates in the Study Groups

\begin{tabular}{|l|l|l|l|l|}
\hline & $\begin{array}{l}\text { Control } \\
(\mathrm{n}=11)\end{array}$ & $\begin{array}{l}\text { Ethanol } \\
(\mathrm{n}=6)\end{array}$ & $\begin{array}{l}\text { Anandamide } \\
(\mathrm{n}=10)\end{array}$ & $\begin{array}{l}\text { WIN } \\
(\mathrm{n}=5)\end{array}$ \\
\hline Mortality & $5(45.50 \%)$ & $0(0.00 \%)$ & $0(0.00 \%)$ & $1(20.0 \%)$ \\
\hline
\end{tabular}

\section{DISCUSSION}

The results of our study demonstrated that the latency period was significantly higher in the ethanol group after $0.1-0.12 \mathrm{ml}$ ip ethanol injection before the PTZ administration, but no significant differences were found in the duration of epileptic seizures. In the anandamide group, receiving $5 \mathrm{mg} / \mathrm{kg} / \mathrm{ml}$ anandamide ip followed by the PTZ injection, the latency period was significantly higher compared to the PTZ group. Although there was a numerical difference between the anandamide and ethanol groups in favor of the anandamide group, the results were not statistically significant. The difference merely suggests that the anti-convulsive effect of ethanol is enhanced by anandamide, however a similar relationship was not observed between the ethanol group and the group receiving WIN 55.212-2, a synthetic analogue of anandamide. 
The intracellular effects of anandamide occur through two different mechanisms. The first is the inhibition of $\mathrm{N}$ or $\mathrm{P} / \mathrm{Q}$ type calcium ( $\mathrm{Ca}++)$ channels via cannabinoid-1 (CB1) and/or cannabinoid-2 (CB2) receptors and the activation of potassium $(\mathrm{K}+)$ influx channels and mitogen activated protein kinase; this mode of action was studied by using selective receptor antagonists specific for both receptors. The second type of effect does not occur through the two known receptor subtypes but interaction occurs via the $G$ proteins. Stimulation of arachidonic acid release and inhibition of the nexus-mediated $\mathrm{Ca}++$ signaling pathway in astrocytes are examples of such effects [9].

Anandamide binds to the CB1 receptors in humans and rats with relatively high affinity [10], decreases cyclic adenosine monophosphate (cAMP) synthesis $[11,12]$ and reduces $\mathrm{N}$-type $\mathrm{Ca}++$ influx [13]. CB2 receptors are synthesized mainly in immune cells and partly in $B$ lymphocytes (B-cells) and natural killer cells [14]. They are limited to the periphery and are not seen in the central nervous system (CNS).

Anandamide has been shown to protect cerebral cortical neurons in rats during in vitro models of ischemia [15]. Nagayama et al. found that synthetic cannabinoid WIN 55.212-2 reduced ischemic damage in the rat brain [16]. In vitro and in vivo results suggest that endogenous cannabinoids may have a neuroprotective role. Alleviation of the neuroprotective effect of 2-arachidonoylglycerol (2-AG) by SR 141617A, a $\mathrm{CB} 1$ receptor antagonist, clearly indicates that the mechanism is mediated through the cannabinoid receptors [17]. Anandamide and 2-AG may act as neurotransmitters or neuromodulators. There is evidence that they are synthesized in neurons when needed: they can be released from the neurons in association with depolarization and, once released, they are removed from the extracellular space via the membrane transport process $[18,19,20,21]$. Anandamide is suggested to be hydrolyzed to arachidonic acid and ethanolamine by fatty acid amide hydrolase (FAAH) [18, 20, 22, 23].

Increased levels of arachidonoyl ethanolamide anandamide (AEA) have been found in neurological disorders, such as epilepsy. The hydrolysis of AEA was measured by the rate of synthesis of ethanolamine, the product of the AEA (separated from the substrate using activated charcoal). FAAH activity was found to be similar in the epileptic and nonepileptic human cortex $(0.29$ and $0.37 \mathrm{nmol}$ ethanolamine/ $\mathrm{mgr}$ protein/ $\mathrm{min}$, respectively) [24].

The results of the Steffens et al. study suggest that elevated AEA levels during epilepsy resulted from increased synthesis and did not appear to be associated with reduced hydrolysis. The administration of FAAH inhibitors to further enhance the endocannabinoid activity, may be therapeutically useful in treating neuronal hyperexcitability [25]. The results of the Keith A. Kwan Cheung et al. study suggest that, elevated in particular, the cannabinoid cannabidiol (CBD) appears to have anti convulsant and anti-inflammatory properties, and it shows promise for epilepsy treatment. There are a multitude of signaling pathways that involve endocannabinoids, eicosanoids and associated receptors, by which cannabinoids could potentially exert their therapeutic effects. Further research is needed to better characterize these pathways, and consequently, improve the application and regulation of medicinal cannabis [26].

Cannabidivarin (CBDV), the propyl analogue of CBD, showed anti-convulsant properties in preclinical studies, however a plant-derived, purified proprietary formulation of CBDV, recently failed the Phase II randomized clinical trial (RCT) in patients with uncontrolled focal seizures [27].

CBD anticonvulsant effects are associated with a great variety of mechanisms of action such as endocannabinoid and calcium signaling. CBD has shown effectiveness in the clinical scenario for epilepsies but its effects on epilepsy-related comorbidities are scarce, even in basic research. More detailed and complex behavioral evaluation about CBD effects on seizures and epilepsyrelated comorbidities are required [28].

CBD has a clear interaction with clobazam, significantly increasing the levels of its active metabolite $\mathrm{N}$-desmethylclobazam in several studies: this is felt to be due to CBD's inhibition of CYP2C19. Expanded access program (EAP) data demonstrates other possible interactions 
with rufinamide, zonisamide, topiramate, and eslicarbazepine. Additionally, there is one case report demonstrating the need for warfarin dose adjustment with concomitant CBD. Our understanding of CBD's efficacy and safety in the treatment of temporal region epilepsy (TRE) has expanded significantly in the last few years. Future controlled studies of various ratios of CBD and $\Delta$-tetrahydrocannabinol (THC) are needed however, as there could be further therapeutic potential of these compounds for patients with epilepsy [29].

A single dose of WIN 55.212.-2 administered soon after status epilepticus (SE) improved survival of animals and reduced cell loss in the dentate hilus but did not prevent appearance of spontaneous recurrent seizures in the chronic period. Thus, a brief pharmacological stimulation of the endocannabinoid system soon after a brain insult exerts beneficial effects on its pathological outcome though does not prevent epileptogenesis [30].

\section{Limitations of Study:}

This study was designed to evaluate the effect of anandamide on pentylenetetrazole induced epileptic seizures in small animals, by determining which types of cannabinoid receptors are. The result of this small experimental study was obtained with a limited numbers of experiments and experimental groups, principally as a result of economic constraints. Therefore, we concluded that in order to clarify the relationship between endocannabinoids and epilepsy, it would be necessary to add the WIN 55.212-2 group, which we did not do. In addition, studies should be conducted with other analogues, specific receptor agonists-antagonists and in particular, concentrations of ethanol in order to clarify the ethanol relationship.

\section{CONCLUSION}

As an interpretation of our results, it can be said that the observed antiepileptic effect of endocannabinoid anandamide is due to the effect of its solvent, ethanol, however this effect was not found with its analogue WIN 55.2122. Although both endocannabinoids affect the CB1 and CB2 receptors, this difference between their effects may be the result of their different pharmacokinetics, metabolisms, or perhaps their degradation products and active metabolites.

Finally, we acknowledge that the findings from our current study require further validation. Future studies will build further on our existing pilot data, involve increased numbers of mice, use different or specific receptor agonist of endocannabinoids, as well as further explore the interaction of ethanol in various concentrations.

Conflict of Interest: The authors have no relevant conflicts of interest and received no financial advantage for this experimental study.

Funding Sources: The authors received no financial support.

\section{REFERENCES}

1. German SP, AIda SV, German SM. Effect of extracellular long-time microperfusion of high concentrations of glutamate and glycine on picrotoxin seizure thresholds in the hippocampus of freely moving rats. Brain Res. 2000; 888: 19-25. PMID:11146048 DOI:10.1016/s0006-8993(00)02974-7

2. Rocha L, Briones M, Ackermann RF. Pentylenetetrazole-induced kindling:early involvement of excitatory and inhibitory systems. Epilepsy Res. 1996; 26: 105-113. PMID:8985692 DOI:10.1016/s0920-1211(96)00046-0

3. Urushıtanı M, Nakamızo T, Inoue R. N-methyl-D-aspartate receptor-mediated mitochondrial $\mathrm{Ca}(2+)$ overload in acute excitotoxic motor neuron death: a mechanism distinct from chronic neurotoxicity after Ca(2+) influx. J Neurosci Res. 2001; 63: 377-387. PMID:11223912 DOI:10.1002/1097-4547

4. Prast $\mathrm{H}$, Philippu A. Nitric oxide as modulator of neuronal function. Prog Neurobiol. 2000; 64: 51-68. PMID:11250062 DOI:10.1016/s0301-0082(00)00044-7

5. Osonoe K, Morı N, Suzukı K. Antiepileptic effects of inhibitors of nitric oxide synthase examined in pentylene-tetrazole-induced seizures in rats. Brain Res. 1994; 663: 338340. PMID:7533045 DOI:10.1016/0006-8993(94)91283-1

6. Devane W.A, Hanus L, Breuer A, Pertwe R.G, Stevenson L.A, Gerlin G, Gibson D, Mandembaum A, Ettinger A, Mechoulam R. Isolation and structure of a brain constituent that binds to cannabinoid receptor. Science. 1992; 258: 1946-1949. PMID:1470919 DOI:10.1126/science.1470919

7. Hanus L, Gopher A, Almog S, Mechoulam R. Two new unsaturated fatty acid ethanolamides in brain that bind to the cannabinoid receptor. J. Med. Chem. 1993; 36: 30323034. PMID:8411021 DOI:10.1021/jm00072a026

8. Felder C.C, Nielsen A, Briley E.M, Palkovits M, Priller J, Axelrod J, Nuguyen D.N, Richardson J.M, Riggin R.M, Coppel G.A, Paul S.M, Becker G.W. Isolation and measurement of the endogenous canabinoid receptor antagonist in the brain and peripheral tissues of human and rat. FEBS. Lett. 1996; 393: 231-5. PMID:8814296 DOI:10.1016/00145793(96)00891-5

9. Mechoulam R, Fride E, Di Marzo V. Endocannabinoids. Eur. J. Pharmacol. 1998; 359: 1-18. PMID: 9831287 DOI: 10.1016/s0014-2999(98)00649-9

10. Felder C. C, Briley E. M, Axelrod J. Anandamide, an endogenous cannabimimetic eicosanoid, binds to the cloned human cannabinoid receptor and stimulates receptor-mediated signal transduction. Proc. Natl. Acad. Sci. U.S.A. 1993; 90: 7656-7660. PMID:8395053PMCID:PMC47201 DOI:10.1073/pnas.90.16.7656

11. Mackıe K, Devane W. A, Hılle B. Anandamide, an endogenous cannabinoid, inhibits calcium currents as a partial agonist in N18 neuroblastoma cells. Mol. Pharmacol. 1993; 44: 498-503. PMID:8371711

12. Pertwee R. G. Pharmacology of cannabinoid $\mathrm{CB} 1$ and $\mathrm{CB} 2$ receptors. Pharmacol Ther. 1997; 4: 129-180. PMID:9336020 DOI:10.1016/s0163-7258(97)82001-3

13. Hansen H. S, Moesgaard B, Hansen H. H, Schousboe A, Petersen G. Formation of $\mathrm{N}$-acyl-phosphatidylethanolamine and $\mathrm{N}$-acyl-etholamine (including anandamide) during glutamate-induced neurotoxicity. Lipids. 1999; 34: 327-330. PMID:10419193 DOl:10.1007/bf02562333

14. Hansen H. H. Anandamide, but not 2-arachidonylglycerol, accumulates during in vivo neurodegeneration. J Neurochem. 2001; 78: 1415-1427. PMID:11579150 DOI:10.1046/ j.1471-4159.2001.00542.x

15. Sinor A. D, Irvin S. M, Greenberg D. A. Endocannabinoids protect cerebral cortical neu- 
rons from in vitro ischemia in rats. Neurosci Lett. 2000; 278: 157-160. PMID:10653017 DOI:10.1016/s0304-3940(99)00922-2

16. Nagayama T, Sinor A. D, Simon R. P, Chen J, Graham S. H, Jin K, Greenberg D. A. Cannabinoids and neuroprotection in global and focal cerebral ischemia and in neuronal cultures. J Neurosci. 1999; 19: 2987-2995. PMID:10191316 PMCID:PMC6782289

17. Mechoulam R. Discovery of endocannabinoids and some random thoughts on their possible roles in neuroprotection and aggression. Prostaglandins Leukot Essent Fatty Acids. 2002 Feb-Mar;66(2-3):93-9. PMID:12052029 DOI:10.1054/plef.2001.0340

18. Di Marzo V, Melck D, Bisogno T, De Petrocellis L. Endocannabinoids: endogenous cannabinoid receptor ligands with neuromodulatory action. Trends Neurosci. 1998; 21 521-528. PMID:9881850 DOI:10.1016/s0166-2236(98)01283-1

19. Piomelli D, Beltramo M, Glasnapp S. Structural determinants for recognition and translocation by the anandamide transporter. Proc Natl Acad Sci USA. 1999; 96: 5802-5807. PMID:10318965 PMCID:PMC21941 DOI:10.1073/pnas.96.10.5802

20. Di Marzo V. Biosynthesis and inactivation of endocannabinoids:relevance to their proposed role as neuromodulators. Life Sci. 1999; 65: 645-655. PMID:10462065 DOI:10.1016/s0024-3205(99)00287-8

21. Hillard C. J, Jarrahian A. The movement of $\mathrm{N}$-arachidonoylethanolamine (anandamide) across cellular membranes. Chem Phys Lipids. 2000; 108: 123-124 PMID:11106786 DOI:10.1016/s0009-3084(00)00191-2

22. Maccarrone M, Van Der Stelt M, Rossi A, Veldink G. A, Vliegenthart J. F. G, Finazzi Agro A. Anandamide hydrolysis by human cells in culture and brain. J Biol Chem. 1998; 273 32332-32339. PMID:9822713 DOI:10.1074/jbc.273.48.32332

23. Ueda N, Puffenbarger R. A, Yamamoto S. Deutsch D. G. The fatty acid amide hydrolase (FAAH). Chem Phys. 2000; 108: 107-121. PMID:11106785 DOI:10.1016/s00093084(00)00190-0

24. Steffens M, Schulze-Bonhage A, Surges R, Feuerstein TJ. Fatty acid amidohydrolase in human neocortex-activity in epileptic and non-epileptic brain tissue and inhibition by putative endocannabinoids. Neurosci Lett. 2005 Sep 2;385(1):13-7. PMID: 15923084 DOI: 10.1016/j.neulet.2005.05.019

25. Steffens M, Schulze-Bonhage A, Surges R, Feuerstein TJ. Fatty acid amidohydrolase in human neocortex-activity in epileptic and non-epileptic brain tissue and inhibition by putative endocannabinoids.Neurosci Lett. 2005 May. PMID:15923084 DOI:10.1016/j. neulet.2005.05.019

26. Keith A. Kwan Cheung 1, Hassendrini Peiris 1 , Geoffrey Wallace 2, Olivia J. Holland 1,3 and Murray D. Mitchell. The Interplay between the Endocannabinoid System, Epilepsy and Cannabinoids.Int.J.Mol.Sci 2019, 20(23), 6079 PMID:31810321 PMCID:PMC6929011 DOI:10.3390/ijms20236079

27. Morano A, Fanella M, Albini M, Cifelli P, Palma E, Giallonardo AT, Di Bonaventura C. Cannabinoids in the Treatment of Epilepsy: Current Status and Future Prospects. Neuropsychiatr Dis Treat. 2020 Feb 7;16:381-396. eCollection 2020. Review. PMID: 32103958 DOI: $10.2147 /$ NDT.S203782.

28. Lazarini-Lopes W, Do Val-da Silva RA, da Silva-Júnior RMP, Leite JP, Garcia-Cairasco $\mathrm{N}$. The anticonvulsant effects of cannabidiol in experimental models of epileptic seizures: From behavior and mechanisms to clinical insights. Neurosci Biobehav Rev. 2020 Apr;111:166-182. doi: 10.1016/j.neubiorev.2020.01.014. Epub 2020 Jan 16. PMID: 31954723 DOI:10.1016/j.neubiorev.2020.01.014

29. Gaston TE, Szaflarski JP. Cannabis for the Treatment of Epilepsy: an Update. Cur Neurol Neurosci Rep. 2018 Sep 8;18(11):73. Review. PMID: 30194563 DOI:10.1007| s11910-018-0882-y.

30. Suleymanova EM, Shangaraeva VA, van Rijn CM, Vinogradova LV. The cannabinoid receptor agonist WIN55.212 reduces consequences of status epilepticus in rats. Neuroscience. 2016 Oct 15;334:191-200. Epub 2016 Aug 9. PMID: 27520083 DOI: 10.1016/j. neuroscience.2016.08.004 